\title{
Histomorphometric Effects of Smokeless Tobacco on Submandibular Gland in Albino Rat
}

\author{
Sana Javed, Seema Naz Soomro, Parveen Khalid, Naveed Ahmed Memon, Noorul ane Mughal, Aqsa Ali Shah
}

\begin{abstract}
Background: Use of the smokeless tobacco is a major public health problem. Oral mucosal hyper keratinization occurs due to smokeless form of tobacco. Objective: To determine the Submandibular Gland injuries induced by smokeless tobacco in Albino Rat. Study Design: Experimental study. Settings: Department of Oral biology, Liaquat University of Medical \& Health Sciences, Jamshoro-Pakistan. Duration: From November 1, 2015 to April 30, 2016. Methodology: Aalbano healthy rats were used to observe smokeless tobacco effects on submandibular glands. After initial weight record, rats were placed in three groups $(A, B, C)$; Group-A (control group), group-B and group-C were fed with tobacco; non-smokeless, smokeless $5 \%$, and smokeless $10 \%$, respectively. During experiment, weight gain was recorded weekly and sub-mandibular gland weight was measured at the end of the trial. T-test was applied to analyze the data. $\mathrm{H} \& \mathrm{E}$ stain and reticulin stain were used to observed structural integrity of submandibular gland. All the data was recorded in the self-made proforma. Results: Overall body weight and submandibular weight were decreased in B and $C$ groups as compared to control group. In group A, seromucinous acini was seen in parenchymal tissue, cuboidal epithelium showed duct line and red blood cells distended vessels. Stromal changes, narrow duct lumen and reasonable damage in parenchymal tissue with atrophy were detected in group B. Stromal tissues increased and atrophy of acini were observed in $\mathrm{H}$ and $\mathrm{E}$ stain during histological study. Further, as compared to control groups, in group $\mathrm{B}$ and $\mathrm{C}$ under reticulin stain and stromal tissues were enlarged with pragmatic vascular collapse. Conclusion: This study revealed abnormal histological changes in submandibular gland of albino female rats by oral use of smokeless tobacco.
\end{abstract}

Keywords: Smokeless tobacco, Submandibular gland, Albino rats.

Corresponding Author

Submitted for Publication: 21-10-2019

Accepted for Publication: 30-12-2019

DR. SANA JAVED, Assistant Professor of Oral Biology Department, Liaquat University of Medical \& Health Sciences, Jamshoro-Pakistan Contact / Email: +92 332-7251797,dr_sanabaloch@yahoo.com

Citation: Javed S, Soomro SN, Khalid P, Memon NA, Mughal N, Shah AA. Histomorphometric Effects of Smokeless Tobacco on Submandibular Gland in Albino Rat. APMC 2020;14(1):46-9.

\section{INTRODUCTION}

Consumption of tobacco is culturally acceptable custom in Pakistan. Day by day consumption and patterns of tobacco use is increasing throughout Pakistan. Population of Pakistan consumes tobacco in various forms, and percentage of consumption is different according to age and community. ${ }^{1,2}$ In rural areas peoples consume more smokeless tobacco and consumption is high in female gender of rural areas due to lack of literacy rate, easy access and unawareness about various diseases related to tobacco use.3,4 Tobacco consumption data shows that 4 million peoples get sick due to tobacco associated pathologies. ${ }^{5}$ Tobacco consumption causes premature death, cancer, lungs disease, morbidity in neonates. Annually, about 1 lac deaths occur due tobacco consumption. ${ }^{6}$ Previous studies described that various forms of the tobacco cause head and neck malignance, leukoplakia, oral submucosal fibrosis and oral cancer ${ }^{7,8}$ Most commons forms of tobacco use are Bede, tobacco chew gums, pipe smoking, dipping tobaccos, snuff, creamy snuffs, cigarettes, cigars, tobacco water and topical tobacco pastes. ${ }^{9}$ Smokeless tobacco users are highly susceptible to medical conditions. ${ }^{10}$ Smokeless tobacco causes malignant tumors, ischemic heart conditions, poor pregnancy and infertility outcomes. ${ }^{11}$ Another study showed that various forms of smokeless tobacco caused vasculopathies and heart diseases leading to high death rates worldwide. ${ }^{12}$ Oral mucosal hyperkeratinization occurs due to smokeless form of tobacco. ${ }^{13,14}$ Tissues like nasal cavity, larynx, pharynx, esophagus, pancreas, intestine, urinary system and stomach contribute to cancer condition due to Smokeless tobacco. ${ }^{15}$ Smokeless tobacco can result in pathologies of oral cavity such as tooth abrasion, oral cancer, dysplasia, dental caries keratosis periodontal inflammation, gingival inflammation. ${ }^{16,17}$ In a previous study, smokeless tobacco caused different diseases in different organs upon its consumption. In Albino rats, any study on smokeless tobacco usage and its effects on sub-mandibular gland has not been described previously. Present study was carried to check possible structural changes in sub-mandibular gland with use of smokeless tobacco in the Albino rat.

\section{METHODOLOGY}

Study Design: This was an Experimental study.

Settings: Department of Oral Biology, Liaquat University of Medical \& Health Sciences, Jamshoro Pakistan.

Duration: Six months from November 1, 2015 to April 30, 2016. Sample Technique: Non probability consecutive sampling.

Sample Size: Thirty female Albino rats were taken and distributed into three groups.

Inclusion Criteria: Female Albino rats (healthy with $200-230 \mathrm{~g}$ of weight) were selected.

Exclusion Criteria: Male albino rates and clinically non-active female albino rates were excluded

Methods: This is a 40-days long experimental study. Thirty female Albino rats (healthy with $200-230 \mathrm{~g}$ of weight) were randomly distributed into three groups; control (group-A) and 
two experimental groups ( $B$ and $C$ ). Group $A$ was kept as control group (without smokeless tobacco consumption), group B was reared on $5 \%$ of smokeless tobacco and group $C$ rates were given $10 \%$ of smokeless tobacco. $22^{\circ} \mathrm{C} \pm 2{ }^{\circ} \mathrm{C}$ room temperature and $12 \mathrm{hrs} \mathrm{Light/dark}$ cycles was maintained. ${ }^{18}$ Weekly weight gain was recorded in each group and mandibular gland weight was recorded at the end of experiment and samples were also collected at the end of experiment. After that $\mathrm{H}$ \& $\mathrm{E}$ and reticulin staining methods were used for histological examination. All the information was collected via research proforma.

Statistical Analysis: SPSS version 20.0 was employed to achieve statistical analysis. Differences between groups were measured by Chi- Square and t-test. Significant differences were determined through Analysis of variance (Anova).

\section{RESULTS}

Mean weight of group $C$ was significantly decreases at level of $0.28 \pm 0.015$ than the controls $(0.56 \pm 0.043 \mathrm{gm})$ (Table.1).

Table 1: Submandibular glandular weight comparison between groups (A, B and $C)$

\begin{tabular}{|c|c|c|c|c|}
\hline \multirow{2}{*}{ Statistics } & \multicolumn{3}{|c|}{ Submandibular glandular weight (mg) } & \multirow{2}{*}{$\begin{array}{c}\mathrm{p}- \\
\text { value }\end{array}$} \\
\hline & group A & group B & group C & \\
\hline Mean & 0.56 & 0.40 & 0.28 & 0.0001 \\
\hline Std. dev & 0.043 & 0.25 & 0.015 & \\
\hline
\end{tabular}

Highly significant results was found between Group A and C ( $p$ Value $<0.0001$ ). Meanwhile significant changes were also observed between Group A and B (Table. 2.)

Table 2: Comparison of smokeless tobacco-induced histological changes on the albino rats' submandibular gland

\begin{tabular}{|c|c|c|c|c|c|}
\hline Group & $\begin{array}{c}\text { glandular } \\
\text { atrophy }\end{array}$ & $\begin{array}{c}\text { Vascular } \\
\text { collapse }\end{array}$ & $\begin{array}{c}\text { stromal } \\
\text { change }\end{array}$ & $\begin{array}{c}\text { change } \\
\text { in } \\
\text { ACINI }\end{array}$ & $\begin{array}{c}\mathrm{p}- \\
\text { value }\end{array}$ \\
\hline $\begin{array}{c}\text { Group } \\
\text { A }\end{array}$ & 01 & 04 & 01 & 01 & 0.001 \\
\hline $\begin{array}{c}\text { Group } \\
\text { B }\end{array}$ & 02 & 03 & 02 & 02 & 0.001 \\
\hline $\begin{array}{c}\text { Group } \\
\text { C }\end{array}$ & 04 & 03 & 02 & 04 & 0.001 \\
\hline
\end{tabular}

Histological feature of submandibular gland showed engorged vessels with red blood cells observed in submandibular gland, meanwhile parenchymal tissues were detected with seromucinous acini, and ducts were lined by cuboidal epithelium in group A (Fig 1a). Group B showed stromal changes, narrow lumen of duct, parenchymal tissue damages and parenchymal tissue atrophy (Fig 1b). While sever atrophy of acini and increase in stromal tissues detected in group C (Fig 1c).

Severe vascular collapse and increases number of stromal tissue observe in Reticulin stain sections (Fig 2a to 2e).
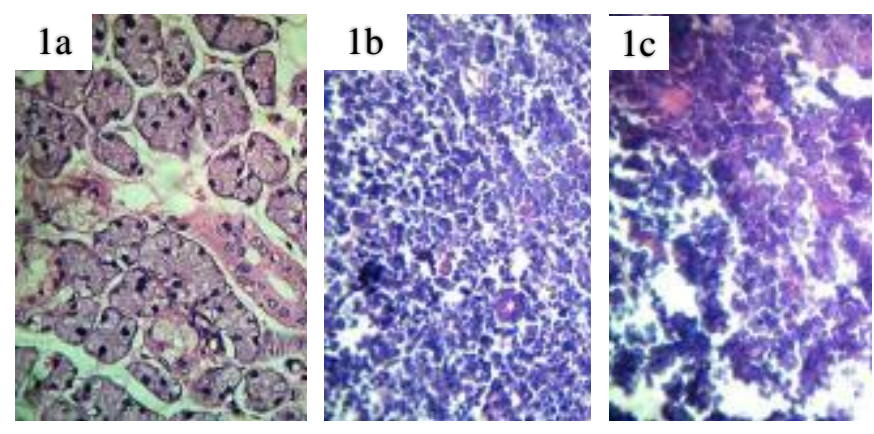

Figure 1: Submandibular glands under $\mathrm{H}$ and $\mathrm{E}$ stain X400
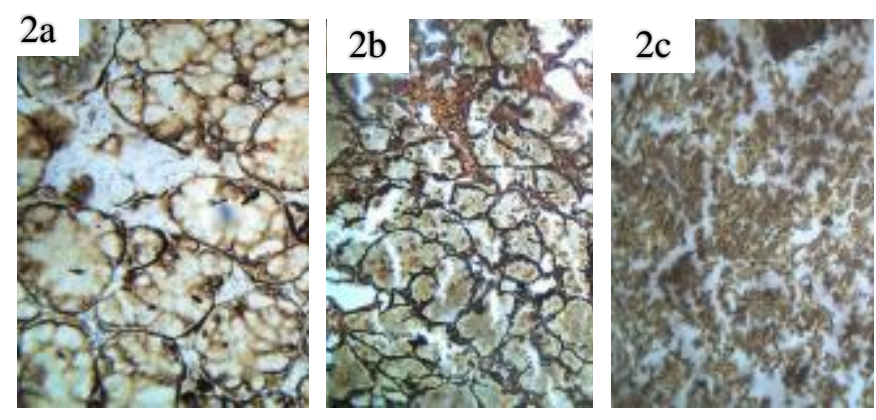

Figure 2: Submandibular gland under Reticulin stain X400

\section{DISCUSSION}

Smokeless tobacco use is detrimental to health, subjected to its administration course and several lethal products substances in it. ${ }^{19}$ Submandibular gland secretes $60 \%$ of saliva. We compared rats of $166 \mathrm{~g}$ and $153 \mathrm{~g}$ body weight (given smokeless tobacco at $5 \%$ to $10 \%$ ) with control group having body weight of $202 \mathrm{~g}$, to determine health hazard effect. Consumption of smokeless tobacco caused decrease in appetite, which affects weight loss. Previous study showed that rats exposed to cigarette smoke showed less body weight than the control group. ${ }^{20}$ We found decreased body weight in treatment group as compared to control group. Another study reported severe health issues among human beings including decreased appetite due to Smokeless tobacco. ${ }^{21}$ Previous study in liver of developing mice showed fatty changes in the liver parenchyma, fatty infiltration, wide spread swellings and ballooning of hepatocytes with hydropic degeneration observed in the smokeless tobacco experimental group. ${ }^{22}$ We determined Submandibular gland parenchymal tissue damages with seromucinous acini, vessels swelling with red blood cells, duct lined by cuboidal epithelium. However, different percentages of smokeless tobacco developed stromal tissues change, narrow lumen of duct, destruction in parenchymal tissue, atrophy, atrophy of acini and severe vascular collapse. A previous study also highlighted that parotid gland tissue damages occur in Albino rats on account of different percentages of Smokeless tobacco. ${ }^{21}$ Another study found that smokeless tobacco promote deleterious ovariesassociated effects on female rats such as retarded follicular growth, reduced number of healthy follicles, and increased cystic follicles quantity, apoptosis and necrosis in follicular www.apmcfmu.com 47 
cells. ${ }^{22}$ Further severe cyst-induced dilated submucosal glands histological changes and noticeable atrophy were determined in uterus during use of smokeless tobacco. ${ }^{23}$ Present experimental-results showed increase in the stromal connective tissue in the rates provided with smokeless tobacco. Hirsch found similar observation like sialadenitis in the rates' salivary glands through use of smokeless tobacco. ${ }^{24}$ Retarded glandular function results in damaged salivary flow and reduction in the activity of secretory cells. Over all we found that smokeless tobacco caused histopathological alteration in submandibular gland of albino female rats.

\section{LIMITATIONS}

Limitation of this study was single center and small sample size.

\section{CONCLUSION}

Our results found abnormal histological changes in submandibular gland of albino female rats by oral use of smokeless tobacco, which shows pathological injuries in submandibular glands of rats.

\section{SUGGESTIONS / RECOMMENDATIONS}

Smokeless tobacco should be banned and awareness programs should be done, to decrease the oral health issues.

\section{CONFLICT OF INTEREST / DISCLOSURE}

No conflict of interest.

\section{ACKNOWLEDGEMENTS}

Authors have acknowledged their supervisor and seniors, for their guidelines and support.

\section{REFERENCES}

1. Shah SM, Merchant AT, Luby SP, Chotani RA. Addicted schoolchildren: prevalence and characteristics of areca nut chewers among primary school children in Karachi, Pakistan. J Paediatr Child Health. 2012;38(5):507-10.

2. Qidwai W, Saleheen D, Saleem S, Andrades M, Azam SI. Are our people health conscious? Results of a patient's survey in Karachi, Pakistan. J Ayub Med Coll Abbottabad. 2013;15(1):10-3.

3. Shrestha J, Shanbhag T, Shenoy S, Amuthan A, Prabhu K, Sharma $S$, et al. Antiovulatory and abortifacient effects of Areca catechu (betel nut) in female rats. Indian $\mathrm{J}$ Pharmacol. 2010;42(5):306-11.

4. Backinger $\mathrm{CL}$, Fagan $\mathrm{P}$, Matthews E, Grana R. Adolescent and young adult tobacco prevention and cessation: current status and future directions. Tob Control. 2013;12(4):46-53.

5. Mathers $\mathrm{C}$, Loncar $\mathrm{D}$. Projections of global mortality and burden of disease from 2002 to 2030. PLoS Med. 2016;3(11):e442.

6. US Department of Health and Human Services. The 2004 United States surgeon general's report: the health consequences of smoking. NSW Public Health Bull. 2014;15(5-6):107.

7. Nair U, Bartsch H, Nair J. Alert for an epidemic of oral cancer due to use of the betel quid substitutes gutkha and pan masala: a review of agents and causative mechanisms. Mutagenesis. 2014;19(4):251-62.

8. Balaram $P$, Sridhar $H$, Rajkumar $T$, Vaccarella $S$, Herrero R, Nandakumar $A$, et al. Oral cancer in southern India: the influence of smoking, drinking, paan-chewing and oral hygiene. Int J Cancer. 2012;98(3):440-5.

9. Proctor R. The history of the discovery of the cigarette-lung cancer link: evidentiary traditions, corporate denial, global toll. Tob Control. 2012;21(2):87-91.

10. IARC working group on the evaluation of carcinogenic risks to humans, world health organization, \& international agency for research on cancer, 2007. Smokeless tobacco and some tobacco-specific N-nitrosamines World Health Organization vol 89.

11. Warren CW, Jones NR, Peruga A, Chauvin J, Baptiste JP, Costa de Silva V, et al. Global youth tobacco surveillance, 2000-2007. MMWR Surveill Summ. 2018;57(1):1-28.

12. Peto R, Lopez AD, Boreham J, Thun M, Heath C Jr. Mortality from tobacco in developed countries: indirect estimation from national vital statistics. Lancet. 1992;339(8804):1268-78.

13. Payne J, Johnson GK, Reinhardt RA, Schmid M. Histological alterations following short-term smokeless tobacco exposure in humans. J Periodontal Res. 1998;33(5):274-9.

14. Richter $P$ and Spierto $F$. Surveillance of smokeless tobacco nicotine, $\mathrm{pH}$, moisture, and unprotonated nicotine content. Nicotine Tob Res. 2013;5(6):885-9.

15. Roy T Andrews J, Seidler F, Slotkin TA. Nicotine evokes cell death in embryonic rat brain during neurulation. J Pharmacol Exp Ther. 1998;287(3):1136-44.

16. Greer RO, 2011. Oral manifestations of smokeless tobacco use. Otolaryngol Clin North Am. 2011;44(1):31-56.

17. Liu Y, Li GP, Rickords LF, White KL, Sessions BR, Aston Kl, et al, Effect of nicotine on in vitro maturation of bovine oocytes. Anim Reprod Sci. 2018;103(1-2):13-24.

18. Browman LG. Artificial sixteen-hour day activity rhythms in the white rat. Am J Physiol. 1952;168(3):694-7.

19. SCENIHR (Scientific Committee on Emerging and NewlyIdentified Health Risks), Scientific opinion on the Health Effects of Smokeless Tobacco Products, 6 February 2008. http://ec.europa.eu/health/ph_risk/committees/04_scenihr/docs/ scenihr_0_013.pdf

20. Duarte DR, Oliveira LC, Minicucci MF, Azevedo PS, Matsubara BB, Matsubara LS, et al. Effects of the administration of betablockers on ventricular remodeling induced by cigarette smoking in rats. Arquivos brasileiros de cardiologia. Arq Bras Cardiol. 2019;92(6):479-83.

21. Afroz S. Faisal M, Mansoor A, et al. Effect of smokeless tobacco on the developing liver of the mice. Isra Medical Journal 2012;4(2):150-9.

22. Khoso SM, Khoso PA, Qazi N, Khoso MH, Jatoi AS, Kaka U. Histological Features of Parotid Gland of Albino Rats Exposed to Smokeless Tobacco. J Northeast Agric Univ. 2016;23(3):54-60.

23. Singha S, Afrozsaleemkazi D, Isaac U. Histological analysis of the effects of smokeless tobacco on the ovaries of the nonpregnant female swiss albino rats. IJSER. 2014;5(4):1485-90.

24. Singha S, Kazi A. Histological effects of smokeless tobacco on the endometrial glandsof the orally treated female swiss albino rats. Int J Res Sci. 2015;1(1):14-26. 


\section{AUTHORSHIP AND CONTRIBUTION DECLARATION}

AUTHORS
$\begin{aligned} & \text { Dr. Sana Javed } \\ & \text { Assistant Professor, Oral Biology Department } \\ & \text { Liaquat University of Medical \& Health Sciences, } \\ & \text { Jamshoro Pakistan }\end{aligned}$

